4. Рильський Максим. Зібрання творів: У 20-ти т. К.: Наук. думка, 1987. Т.16. Фольклористика, теорія перекладу, мовознавство. 600 с.

5. Ткаченко А. О. Мистецтво слова (Вступ до літературознавства): підручник для гуманітаріїв. К.: Правда Ярославичів, 1997. 448 с.

6. Jakobiec M. Maksym Rylski. Ruch literacki. 1978.Z.4/56.

7. Mickiewicz Adam. Poezje. Ballady i romanse. Sonety. Inne wiersze. Krakow: Eventus, 1994.249 s.

DOI https://doi.org/10.30525/978-9934-26-073-5-2-33

\title{
ЯВИЩЕ МЕТОНІМІЇ В РОМАНІ СЕБАСТЬЯНА ФОЛКСА «BIRDSONG» ТА СПОСОБИ ЙОГО ПЕРЕКЛАДУ УКРАЇНСЬКОЮ МОВОЮ
}

\author{
Мироненко В. О.
}

студентка 4 курсу кафедри теорії та практики з англійської мови

Чорноморського національного університету імені Петра Могили м. Миколаїв, Украӥна

Твори С. Фолкса все більше набувають актуальності за останні десятиліття. Відомий роман «Birdsong» приніс С. Фолксу нагороду «Автор року» від British Book Awards, а за результатами опитувань став однією з найулюбленіших книжок Великої Британії із двома мільйонами проданих примірників. Крізь увесь роман можна простежити явище метонімії, яке визначає заміну звичайних явищ та подій через асоціативний ряд чи сукупність суміжних означень. Даною проблемою займалися такі вчені, як: І. В. Арнольд, І. Р. Гальперін, Н. В. Чернікова, Л. А. Булахівська, М. Р. Шкуропацька тощо.

Ю.І. Ковалів стверджує, що «образність - це своєрідна лінгвістична реалізація відчутної уяви чи певного ряду міркувань, які стали підгрунтям назви конкретного предмета дійсності життя та не 3 однаковим ступенем виразності з'являються в основі внутрішньої форми слова» [2, с. 135].

Фігуральність - це образність, створювана за допомогою різноманітних художніх тропів, які у своєму поєднанні створюють метафоричний, алегоричний, метонімічний або іронічний зміст. Метонімія спосіб утворення нових слів за лексичною ознакою; стилістичний засіб. Метонімія має різні дефініції. Деякі лінгвісти визначають метонімію як 
трансформацію назви за схожістю понять. Інші доповнюють, як заміну однієї назви предмета іншою через наявні відношення однієї до одної.

Метонімію можна перекладати кількома прийомами, проте здебільшого використовують саме дослівний переклад. У такому разі надається еквівалент в мові перекладу, якщо такий існує, або перекладається сам образ. Наприклад: «The best voices of modern pop music gathered in the Hall» - «У залі зібралися найкращі голоси сучасної естради. Якщо дослівний переклад неможливий, то підшукується відповідність, або конструюється нова одиниця, характерна для мови перекладу [5, с. 80].

Існує декілька найпоширеніших способів перекладу метонімії [4, с. 98]. Повний переклад метонімічної одиниці оригіналу застосовується в разі повного збігу мовних особливостей вираження в англійській та українській мовах, як показано в наступному прикладі: «There were footsteps on the stairs, and Isabel's gaze flickered up from the sofa where she was sitting with her afternoon sewing»- «Почулися кроки на сходах, і погляд Ізабель мелькнув вгору 3 дивану, де вона сиділа 3 післяобіднім шиттям». Якщо повний переклад неможливий, то надається аналог або моделюється нова одиниця, характерна для мови перекладу.

Існують метонімічні фразеологізми. Вони дуже часто зустрічаються саме в художньому стилі, адже він передбачає вживання фразеологічних одиниць для вираження прихованого змісту образності. Образні фразеологізми, що вживаються в англійській художній літературі, можна перекласти за допомогою наступних прийомів [1, с. 20]:

- повним еквівалентом 3 подібною структурою, лексичним складом, стилістичними характеристиками, значенням і образністю: «Odeon Square was known as a cook here served a strong man who was once exiled from Paris, where he kept a cafe» - «Одеон славився кухарем тут служив міцний чолов'яга, якого колись вислали з Парижа, де він тримав кафе»;

- неповним відповідником, схожим на текст оригіналу за значенням i стилістичним характеристикам, але відмінний за образом, який використовується, лексичним складом та граматичним ознаками: «from cradle to grave» - «все життя»;

- варіантним відповідником: 3 кількох синонімічних фразеологічних одиниць обирається одна - найбільш адекватна в даному разі: «to be in gold» - «ходити у золоті»;

- описово: переклад без збереження образності: «Suddenly, gentle voice spoke to Azaire» - «Аж раптом хтось 3 ніжним голосом мовив до Азера». Слід перекладати це описово лише тоді, коли неможливий переклад зазначеними вище способами. 
У перекладі метонімії також використовують прийом генералізації значення слова. Наприклад: «tall figure, hands in in his pockets»«висока фігура, руки у кишенях» та «his eyes were patient»- «погляд терплячий».

Трансформація додавання - доповнення перекладу новими лексичними одиницями, які були відсутні в оригіналі. Наприклад, «But at that moment Stephen it seemed that the opposite was true: a new world where they should now live, and that the old world, with its alternation of day and night and seasons, no longer exists» - «Але в той момент Стівенові здавалося, що все навпаки: це і є нова реальність, новий світ, де вони відтепер мають жити, і що старого світу, з його чергуванням дня і ночі та пір року, більше не існує».

Трансформація конкретизації - лексична трансформація, яка передбачає звуження значення лексичної одиниці оригіналу на ії вужчий відповідник у перекладі. Наприклад, «The luxurious cobbled courtyard in front of the railway station invited people who increasingly met someone on the platform»- «Пишний брукований двір перед залізничним вокзалом манив людей, котрі все частіше зустрічали когось на пероні» [3, с. 78].

Використання трансформації логізації зумовлене неоднорідністю культур англо- та україномовного світу. Логізація - це спосіб перекладу заміненням емоційного елементу стилістично нейтральним відповідником. Наприклад: «Once again, the city was plunged into peace which seemed to them an incredible miracle» - «І знову містяни поринули у спокій, який здавався їм неймовірним дивом».

Отже, ми дослідили, що метонімія - це троп або навіть механізм мови, що складається в регулярному перенесенні імені з одного класу на інший клас, або окремий предмет, асоційований з даними по суміжності, а також залученості в одну ситуацію. На нашу думку, найкращий спосіб перекладу даного явища - описовий або еквівалентний. Саме за допомогою зазначених способів можна досягти мовної та культурної відповідності в обох мовах: англійській та українській. Проаналізувавши всі приклади, ми зробили висновок, що в романі С. Фолкса «Birdsong» існує таке співвідношення: 40\% метонімія засобу, 25\% метонімія місця, $20 \%$ метонімія причини та наслідку $15 \%$ метонімія символу та значення. Отже, перекладач використовував різні способи, щоб адекватно відтворити контекст тексту оригіналу в перекладі, дотримуючись всіх правил та норм мови перекладу. Проаналізувавши всі приклади, ми зрозуміли, що у перекладі використано 40\% дослівного перекладу, $25 \%$ описового, $10 \%$ трансформації «додавання», $10 \%$ трансформації «опущення» та 15\% трансформації «логізації». 


\title{
Література:
}

1. Качуровський, I. В. Основи аналізу мовних форм. Стилістика. Фігури. Тропи, Світ, 2011. 86 с.

2. Ковалів, Ю. І. Поетичне мовлення, поетичний стиль, художній стиль. Художньо-белетристичний стиль, Академія, 2007. 320 с.

3. Науменко, Л. П. Основний курс перекладу 3 англійської на українську мову, Нова. Книга, 2016. 136 с.

4. Ткаченко, А.О. Мистецтво слова. Вступ до літературознавства, Наука, 1988. 448 c.

5. Dirven, René. Metonymy and Metaphor: Different Mental Strategies of Conceptualisation. Radden, 2003. 111 p.

DOI https://doi.org/10.30525/978-9934-26-073-5-2-34

\section{ПОНЯТТЯ АДЕКВАТНОСТІ \\ ТА ЕКВІВАЛЕНТНОСТІ ПЕРЕКЛАДУ РОСІЙСЬКИХ ДІЄПРИКМЕТНИКІВ ТА ДІЄПРИКМЕТНИКОВИХ ЗВОРОТІВ УКРАЇНСБКОЮ МОВОЮ}

\author{
Саїк А. В. \\ кандидат філологічних наук, дочент, \\ дочент кафедри філології та мовної комунікації \\ Начіонального технічного університету "Дніпровська політехніка» \\ м. Дніпро, Украӥна
}

Переклад як термін має полісемантичну природу, його найбільш розповсюджене і здебільшого узагальнююче значення пов'язують 3 процесом передачі значення слова, групи слів, речення або уривку з мови оригіналу на мову перекладу. Поняття «переклад» можна визначити так: заміна текстового матеріалу однісї мови (мови оригіналу) еквівалентним текстовим матеріалом іншої мови (мови перекладу) [6 с. 14-19].

Головною метою будь-якого перекладу - $\epsilon$ досягнення адекватності. Адекватність - це вичерпна передача смислового змісту оригіналу i повна функціонально-стилістична відповідність йому. Оскільки зрозуміло, що було б непогано, якби зміст оригіналу та перекладу були тотожними, то можна зробити висновок, що переклад має повністю зберігати зміст оригіналу: повноцінність перекладу означає вичерпну передачу смислового змісту оригіналу і повну функціонально-стилістичну відповідність йому [8, с. 45-47]. Але науковець Л.С. Бархударов 